\title{
From Beveridge to Turner: \\ Demography, Distribution and the Future of Pensions in the UK
}

\author{
John Hills
}

\section{Contents}

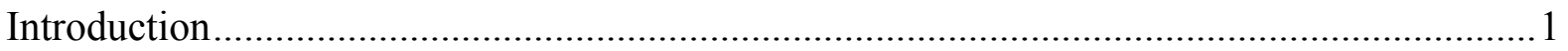

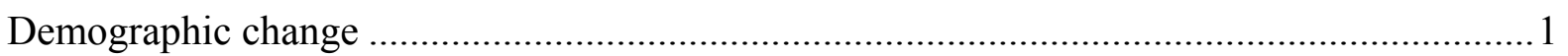

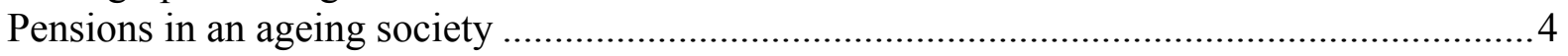

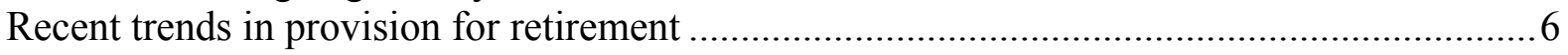

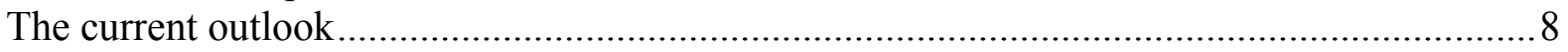

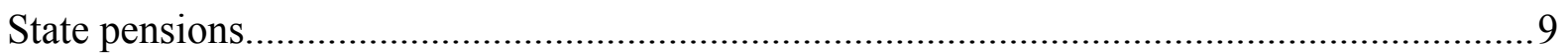

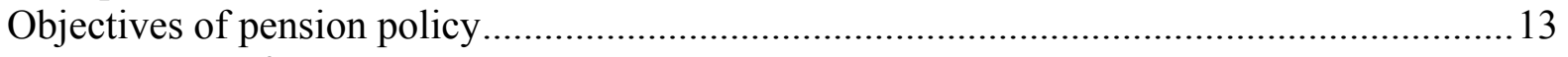

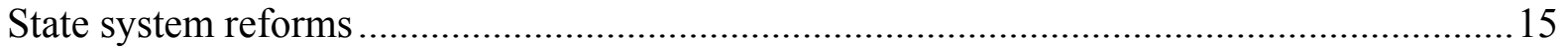

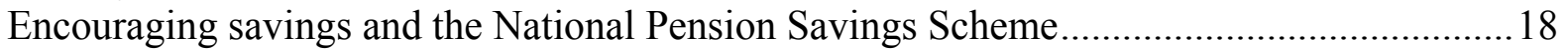

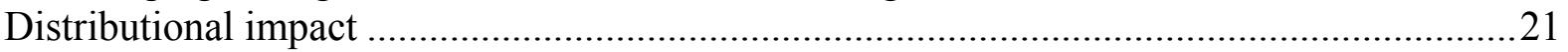

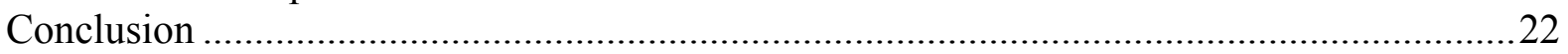

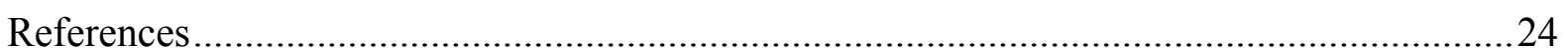

CASE/ 110

June 2006
Centre for Analysis of Social Exclusion

London School of Economics

Houghton Street

London WC2A $2 \mathrm{AE}$

CASE enquiries - tel: 02079556679 


\section{Centre for Analysis of Social Exclusion}

The ESRC Research Centre for Analysis of Social Exclusion (CASE) was established in October 1997 with funding from the Economic and Social Research Council. It is located within the Suntory and Toyota International Centres for Economics and Related Disciplines (STICERD) at the London School of Economics and Political Science, and benefits from support from STICERD. It is directed by Howard Glennerster, John Hills, Kathleen Kiernan, Julian Le Grand, Anne Power and Carol Propper.

Our Discussion Paper series is available free of charge. We also produce summaries of our research in CASEbriefs, and reports from various conferences and activities in CASEreports. To subscribe to the CASEpaper series, or for further information on the work of the Centre and our seminar series, please contact the Centre Manager, Jane Dickson, on:

$\begin{array}{ll}\text { Telephone: } & \text { UK+20 } 79556679 \\ \text { Fax: } & \text { UK+20 79556951 } \\ \text { Email: } & \text { j.dickson@1se.ac.uk } \\ \text { Web site: } & \text { http://sticerd.lse.ac.uk/case }\end{array}$

(C) John Hills

All rights reserved. Short sections of text, not to exceed two paragraphs, may be quoted without explicit permission provided that full credit, including () notice, is given to the source. 


\title{
Editorial Note
}

John Hills is Professor of Social Policy and Director of the ESRC Centre for Analysis of Social Exclusion at the London School of Economics. He was a member of the Pensions Commission with Jeannie Drake and its chair, Adair Turner. This article is based on the Royal Statistical Society's 2005 Beveridge Lecture, which John Hills delivered on $1^{\text {st }}$ December 2005, the day after the Commission's main report was published. It draws heavily on the Commission's reports and therefore on the work and ideas of his fellow Commissioners and of its expert secretariat, to all of whom he is extremely grateful, as he is to the Economic and Social Research Council for funding. The Commission's reports and other material are available on its website at www.pensionscommission.org.uk.

\begin{abstract}
This article outlines the recommendations of the UK Pensions Commission, and the data and analysis on which they were based, including projections of demographic change, trends in private pension saving, and evolution of the state pension system. The Commission concluded that without reform, structural problems with UK pensions would lead to increasingly inadequate and inequitable provision in 15-20 years time. It recommended reforms which would lead to a more generous, more universal and less means-tested state system than would otherwise evolve, and the establishment of a low cost National Pension Savings Scheme, into which employees without good employer provision would automatically be enrolled. The proposals, which have now largely been adopted by the UK government, imply eventual increases both in state spending on pensions as a share of national income and in State Pension Age, but accompanied by measures to facilitate later and more flexible retirement.
\end{abstract}

JEL number: H55

Key words: Demographic change; Pensions; Retirement incomes; Social security. 


\section{Introduction}

The second report of the Pensions Commission (PC, 2005), of which the author was a member, was published two days before the sixty-third anniversary of the publication of Beveridge's great 1942 report, Social Insurance and Allied Services. The day after publication of that report, queues famously formed around HMSO's offices to get copies. There were no such queues the day after our report was published, although there had been more than half a million website hits on downloadable versions of its chapters on the day of publication.

This paper summarises the evidence and arguments behind the Commission's recommendations. A fundamental part of that evidence is the degree to which, in common with other European countries, the UK is an ageing society, with part of this driven not just by rising longevity, but also by rapidly increasing expectations of further longevity improvements in the future.

\section{Demographic change}

Figure 1 shows successive Government Actuary's Department (GAD) principal projections of female (cohort) life expectancy at the age of 65. In the 2001based projections, available to the Commission when we started work in early 2003 , this was projected to rise slowly from a little over 20 years now to just over 21 years for women reaching 65 in 2050. In the most recent, 2004-based projections, the latter figure had risen by four years to nearly 26 years. For men reaching 65 in 2050, projected life expectancy is now 23.6 years, compared to only 19 years in the 2001-based projections. This view of the world for which we are planning pensions policy changed profoundly just while the Commission was sitting.

But, as such revisions illustrate, such projections are inherently highly uncertain. It is instructive to look at the projections Beveridge himself was using in his 1942 report, summarised in Table 1. These suggested that just thirty years ahead, the proportion of the population aged over State Pension Age (60 for women and 65 for men) would have risen from 12 per cent in 1941 to 21 per cent by 1971. In fact, it was only 16 per cent in 1971 and will not - on current projections - reach 21 per cent above what will be the unified SPA of 65 until 2026, before heading rapidly up to 23 per cent in 2031 and 25 per cent in 2050 . 
Figure 1: Women's cohort life expectancy at 65: Government Actuary's Department principal projections

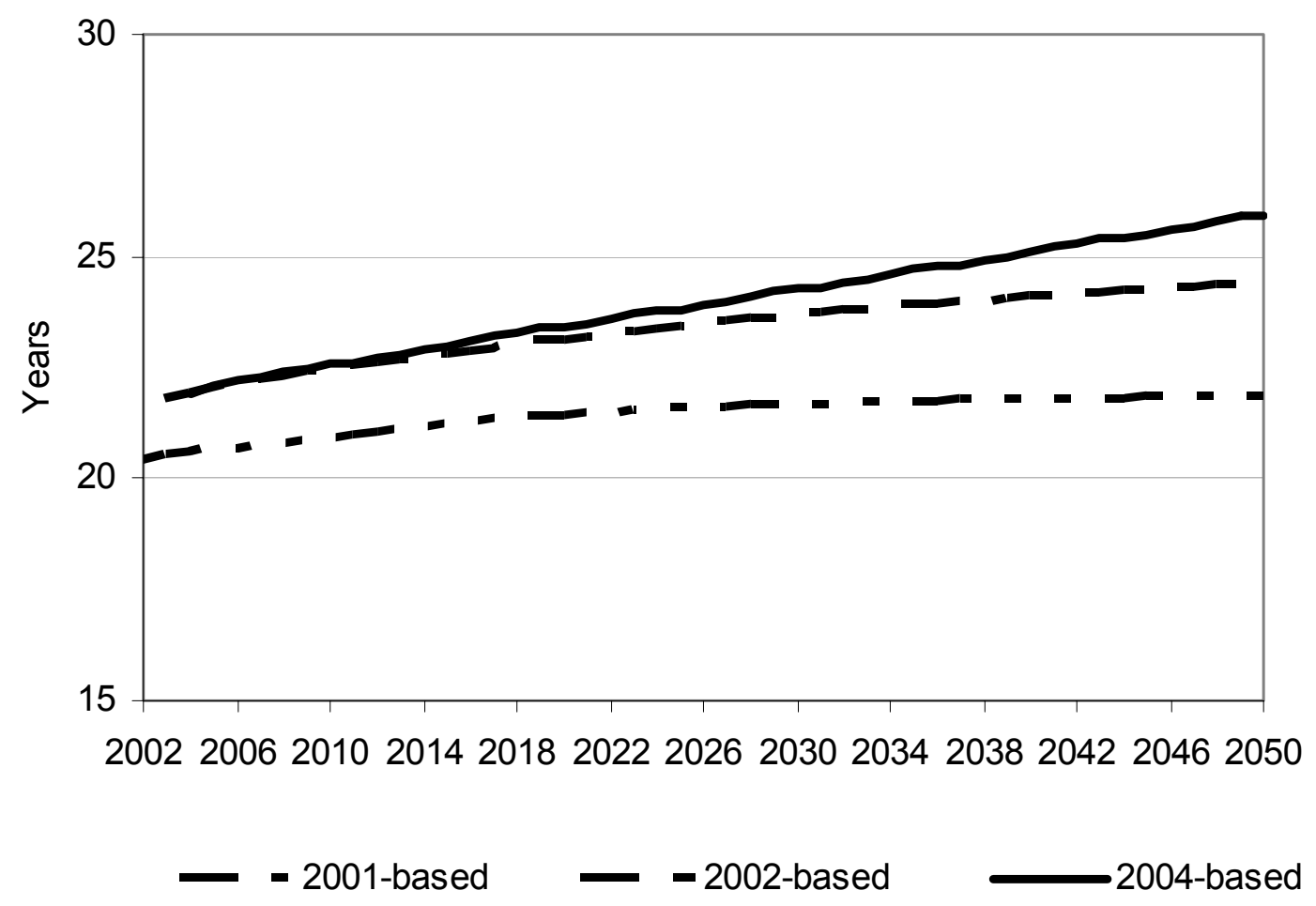

Source: PC (2005), figure 1.38 (derived from GAD, 2005 and earlier equivalents).

Table 1: 1942 and 2005 projections of age structure

\begin{tabular}{lccccc}
\hline \hline & \multicolumn{2}{c}{$\begin{array}{c}\text { Beveridge Report } \\
\text { projections, 1942 (GB) }\end{array}$} & \multicolumn{2}{c}{$\begin{array}{c}\text { Actual } \\
\text { (GB) }\end{array}$} & \multicolumn{2}{c}{ GAD principal } \\
projections, 2005 (UK)
\end{tabular}

*Using population over 16.

Sources: Beveridge (1942); Government Actuary’s Department (2005) and earlier equivalent for 1971 actual population. 
Beveridge and the Government Actuary who advised him did not foresee the post-War baby boom. As well as increasing life expectancy, the second factor driving the increase in the proportion of the population over 65 is the unwinding of the impact of the baby boom. As Figure 2 illustrates, what we now expect to see over the next 25 years is a rapid catch-up to where the old age dependency ratio would have been without the baby boom (the dashed line), if fertility rates had remained at their level of the 1930s, rather than rising above them until the mid-1970s as they actually did (the solid line). Over the next twenty years we will get back to where Beveridge might have thought we would have got to, having had a period of what has been in some ways false security.

Figure 2: Impact of the 1940s-1960s baby boom on the old age dependency ratio

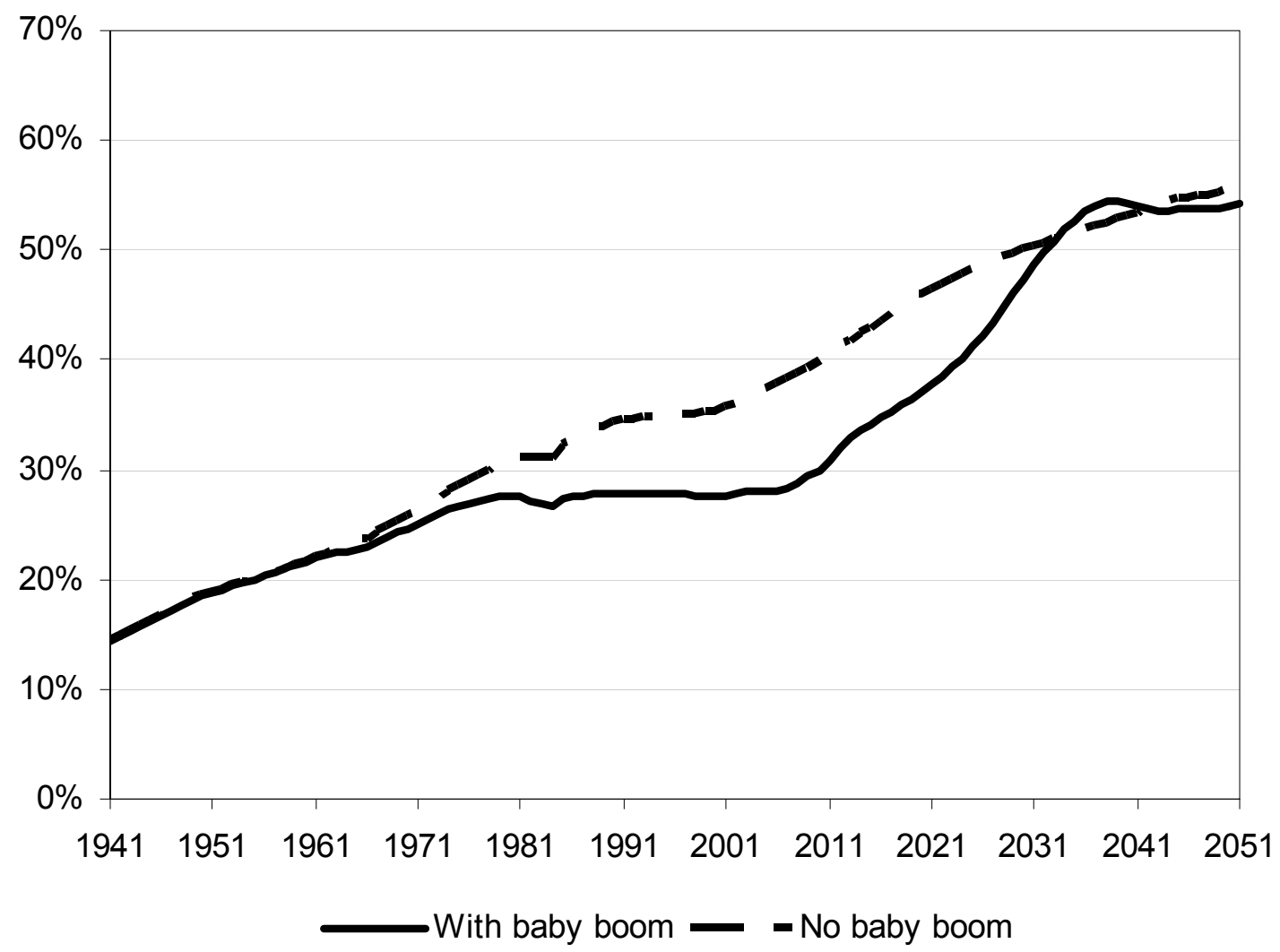

Source: PC (2005), figure Ex.1. Population aged over 65 as proportion of those aged 18-64 (England).

As well as the need to prepare for increasing longevity, a second implication of this is therefore to expect the unexpected, Future demographic structure is highly uncertain. Further life expectancy of 23.6 years for men reaching 65 in 2050 may indeed be the most reasonable projection we can make now, but some would still defend the logic of an effective "limit to life" which produced the projection of 19 years a few years ago. On the other hand, others would point out that even the new higher projection implies quite a rapid slow-down in the 
rate of improvement of age-specific mortality which we have experienced for the last 25 years. If that trend in fact continued, male life expectancy at 65 could reach 29 years by 2050. Similarly, the Continuous Mortality Investigation of the actuarial profession has recently both increased its projections of life expectancy for current 65 year-olds, but also the range of uncertainty to 3.5 years around even this relatively short-term projection. ${ }^{1}$

We thus have to work with best projections, but recognising that they could be wrong. In setting policy it needs to become robust to such uncertainty - which is why as a Commission we would rather policy emerged around principles, such as that "state pension ages should gradually adjust to keep a fixed proportion of adult life in retirement" than to set definitive ages decades ahead that are not adapted as we move forwards into what is now a wide funnel of doubt.

\section{Pensions in an ageing society}

But the best estimates are that longevity is increasing and that the proportion of the population over a given age is increasing. In the Commission's first report (PC, 2004) we said that this left us - and indeed any nation in this position with four choices:

> Pensioners becoming poorer relative to the rest of the population;

$>$ Later retirement;

$>$ A greater amount of tax and/or National Insurance Contributions as a share of national income devoted to state pensions; or

$>$ Greater savings for retirement.

We argued that we found the first option unattractive. So did those giving evidence to us, and those surveyed in research for the Commission (PC, 2005, appendices B and D). When a national deliberative polling session was held by the Department for Work and Pensions around the Commission's proposals in March 2006, at the end of the day's discussions only 12 per cent of the more than one thousand participants thought that relatively poorer pensioners would have to be part of the solution to the UK's pensions problems. By contrast, more than half thought that people would have to work longer, and 80 per cent or more that more taxes would have to be spent on pensions and that people would have to save more for their retirement (PC, 2006, figure 1). When asked how big a role the option of poorer pensioners should play in solving future pensions

1 For more detailed discussion, see PC (2005), Appendix E, based on a lecture given by Adair Turner at the CASS Business School in April 2005. 
problems, participants awarded an average of 0.3 points out of ten to it, as opposed to around three points for each of the other options.

As Figure 3 shows, pensioner poverty (in relative terms) rose sharply in the $1980 \mathrm{~s}$, but since then it has fallen, and one of the present Government's major achievements has been to continue this reduction. Pensioner poverty in 2004-05 at 19 per cent (before housing costs) is 8 percentage points lower than it would have been without the tax and benefit changes since 1997 (Sutherland, 2004).

Figure 3: Pensioners in poverty, 1979 to 2004-05 (percentage with incomes below 60 per cent of population median income adjusted for family size)

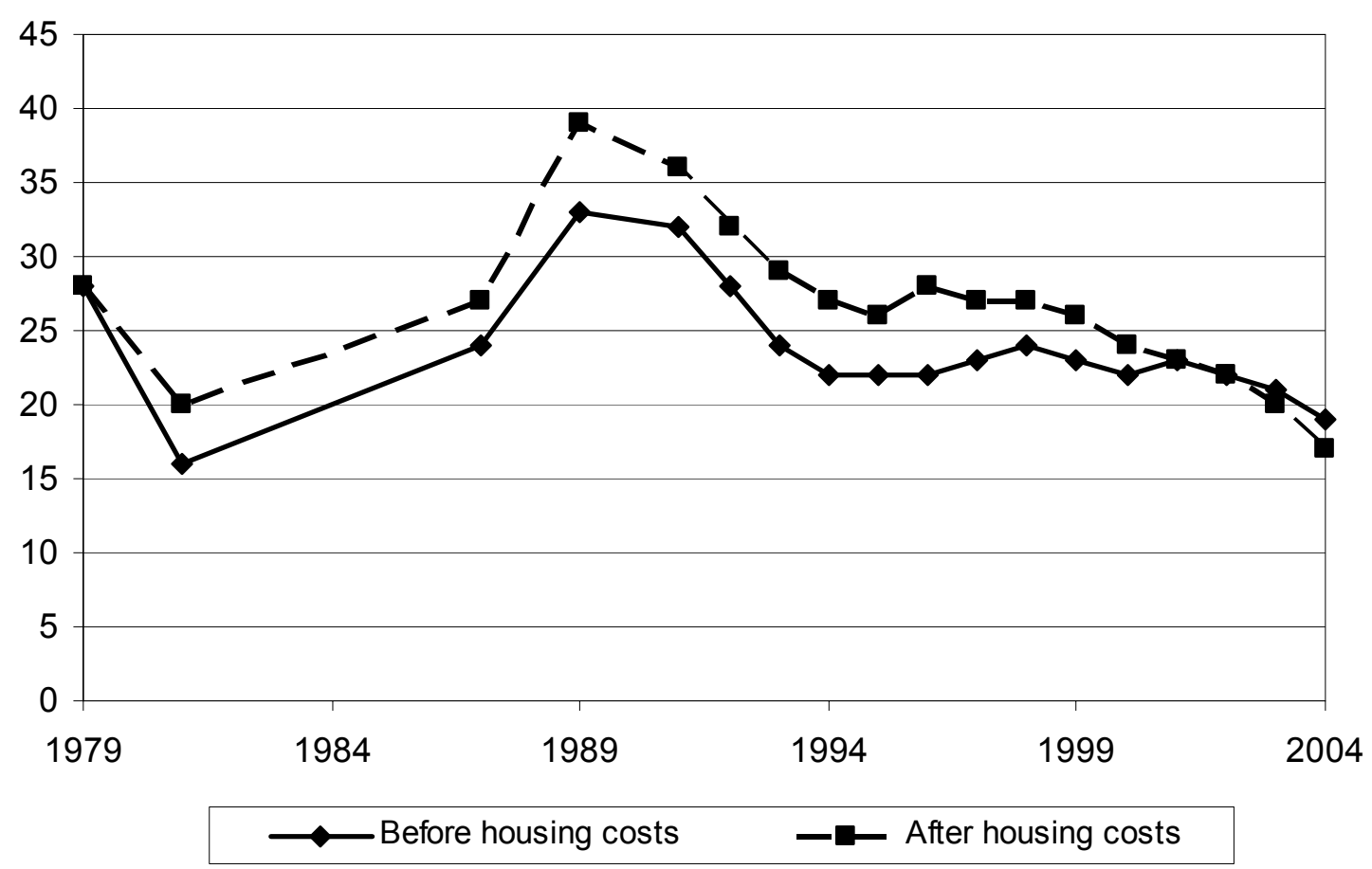

Source: Department for Work and Pensions (2006a).

As a Commission we took it as read that any reforms should be based on protecting the gains this government has made towards the aim spelt out by the Chancellor, Gordon Brown, at the 2002 Labour Party Conference of "ending pensioner poverty in our country". We therefore assumed that the minimum income for pensioners set by what is now called the "Guarantee Credit" should not lose value relative to contemporary living standards. ${ }^{2}$ Future public

2 This principle has now been affirmed as part of government policy in the White Paper responding to the Commission's proposals (DWP, 2006b). 
spending could, of course, be lower if this assumption was relaxed, but only at the cost of increasing pensioner poverty.

\section{Recent trends in provision for retirement}

Our second report therefore spelt out the mixes of the other three options which we thought desirable and achievable. But we did so against a background in which as a nation we are currently reducing rather than increasing provision for future retirement incomes. Inflows into funded pension saving remained at around 3.7 per cent of GDP between 1992 and 2002. More recently they have increased, reaching 4.3 per cent of GDP in 2004 (PC, 2005, figure 1.14). However, of this about 0.7 per cent of GDP represents "catch-up" payments to protect the already promised rights of existing members of private sector "defined benefit" (DB) pension schemes, such as those related to final salaries. The underlying long run flow into funded pension saving is falling - eventually to perhaps just over 3 per cent of GDP (PC, 2005, figure 1.15), allowing for the way in which new employees (and even some existing employees) are being promised "defined contribution" (DC) pensions which are in fact much less generous than given in the past. In the private sector, membership of pension schemes is falling. In 2002-03, 10 million private sector employees contributed to non-state pensions, but 10.5 million did not. By 2004-05, contributors had fallen to under 9 million and non-contributors had risen to over 11.5 million (PC, 2006, figure 2).

At the same time, as discussed in more detail below, the state system has been set to evolve in a way which would mean much lower pensions in relation to earnings for typical earners than being enjoyed now by some of those recently retired and near retirement, who have got the best out of what was the State Earnings Related Pension Scheme (SERPS, now the state second pension).

Meanwhile, Figure 4 shows that effective ages of retirement have fallen considerably over the long term, although there has been a welcome recent reversal - with average effective retirement ages increased by a year in the ten years from 1995 to 2005. The long-run effect, combined with the increasing longevity discussed above, has been a rapid rise in the percentage of adult life spent in retirement from a quarter in the 1950 s to a third for those retiring today (PC, 2005, figure 1.44). 
Figure 4: Trends in mean age at retirement

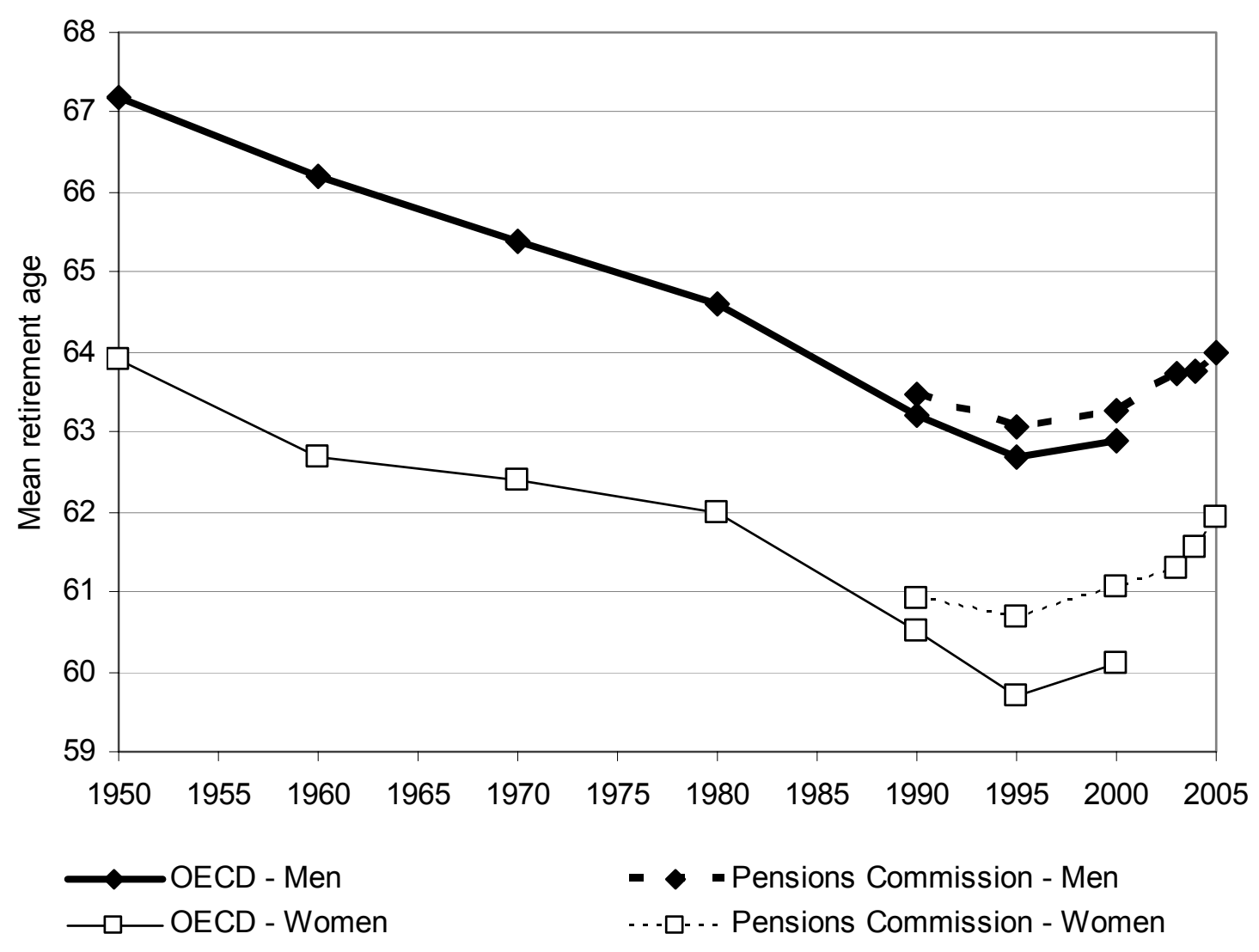

Source: PC (2005), figure 8.3.

But people are not aware that this is happening. Our own surveys confirmed recent Nottingham University research ${ }^{3}$ that younger cohorts simply do not anticipate the increase in their life expectancy that actuaries now predict. There is little difference between the life expectancy implied by people's anticipated retirement date and expected length of retirement between those in their twenties and those in their fifties (Table 2): people judge things by what happened to their grandparents and parents, not by actuarial projections. And recent qualitative research by the Institute for Public Policy Research suggested that some people simply do not believe the projections of increasing life expectancy when put in front of them. The combination of projections of increased future needs, but public lack of knowledge about their scale, makes policy-making very hard.

3 O’Brien, Fenn and Diacon (2005). 
Table 2: Perceptions and projections of life expectancy

\begin{tabular}{lcccccc}
\hline \hline \multirow{2}{*}{$\begin{array}{l}\text { Current } \\
\text { age }\end{array}$} & $\begin{array}{c}\text { Omnibus } \\
\text { survey 2005 } \\
\text { perceptions }\end{array}$ & $\begin{array}{c}\text { GAD 2004- } \\
\text { based } \\
\text { projections }\end{array}$ & Gap & $\begin{array}{c}\text { Omnibus } \\
\text { survey 2005 } \\
\text { perceptions }\end{array}$ & $\begin{array}{c}\text { GAD 2004- } \\
\text { based } \\
\text { projections }\end{array}$ & Gap \\
\cline { 2 - 7 } $16-25$ & 81.1 & 88.5 & -7.4 & 80.7 & 91.0 & -10.3 \\
$26-35$ & 81.4 & 87.6 & -6.2 & 81.4 & 90.1 & -8.7 \\
$36-45$ & 82.2 & 86.7 & -4.5 & 82.6 & 89.2 & -6.6 \\
$46-55$ & 81.9 & 85.9 & -4.0 & 81.3 & 88.4 & -7.1 \\
$56-65$ & 81.7 & 85.1 & -3.4 & 83.6 & 87.7 & -4.1 \\
\hline \hline
\end{tabular}

Source: PC (2005), appendix D, figure D.36. Omnibus survey results based on sum of individual expectations of retirement age and length of retirement. GAD projections based on assumption of survival to 65 on basis that answers for expected length of retirement would be given assuming survival to retirement age.

\section{The current outlook}

Putting all of these trends together, looking 15-20 years ahead, in the absence of change, some retirees will be as well off in relative terms as their equivalents today - including private sector employees who remained as members of generous defined benefit schemes as they closed to new members, and those with good careers in the public sector. If the minimum income for pensioners continues to be linked to average earnings, the same relative protection would apply to many of the poorest pensioners as well.

But there are other groups that already have poor pension provision, such as those with interrupted paid work careers, including many women, and those with low to median earnings working for small and medium-sized organisations. Beyond these, many others, expecting to be as well-off as their equivalent predecessors, are in for a nasty surprise - either not knowing what is coming or hoping "it will be all right on the night" and that "they won't let you starve will they?", as Peter Taylor-Gooby (2005) summed up views found in his recent research. Indeed, if we did do nothing now and "muddled through", it is highly likely that political pressure would force an ad hoc increase in state pensions. But such a muddle-through option is unlikely to be either fair or economically optimal by comparison with what we could achieve if we plan ahead now. 


\section{State pensions}

Recent governments have hoped that the private sector will take more of the strain, keeping public spending in check by linking the basic state pension (BSP) to prices rather than earnings. At the same time, the present government has reformed the state second pension (S2P) and introduced the means-tested Pension Credit to help low earners and protect the poorest pensioners.

It is instructive to see how the state system would change if the indexation arrangements being followed at present were continued. Figure 5 shows the pension that someone retiring in 2005 would receive at that point from the state if they had spent a full paid work career at different earnings levels and had made no private pension saving. Figure 6 shows the same for someone retiring in 2050 under this assumed evolution of the system, all in today's earnings terms. What the figures show is that in effect we would move from a partly earnings-related state pension system to a complex flat-rate system. Indeed, carried to its logical conclusion the system would become somewhat more generous to low-earning non-savers, but it would be much less generous to those with around average earnings with some private pension. For instance, someone with median earnings or above paying the equivalent of 10 per cent or more of earnings above the income tax threshold into a private pension would receive only the basic and second pensions from the state (PC, 2005, figure 4.10). These would together be worth around 25 per cent of median earnings, compared to the $35-50$ per cent of median earnings their equivalents would receive today. 
Figure 5: State pension income at retirement, retiring in 2005, assuming no private saving (\% of median earnings)

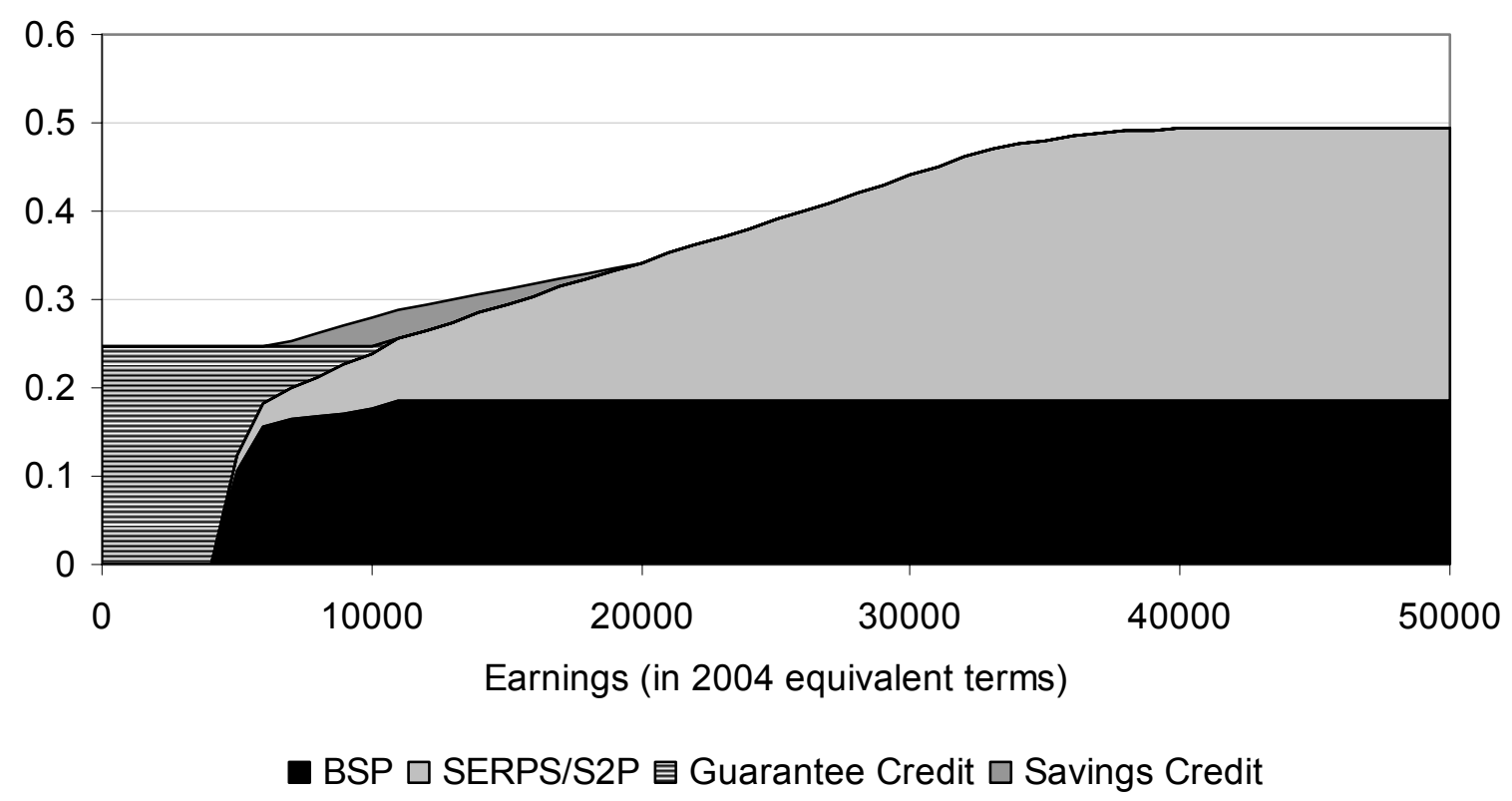

Source: PC (2005), figure 4.7.

Figure 6: State pension income at retirement, retiring in 2050, assuming no private saving ( $\%$ of median earnings), current indexation continued indefinitely

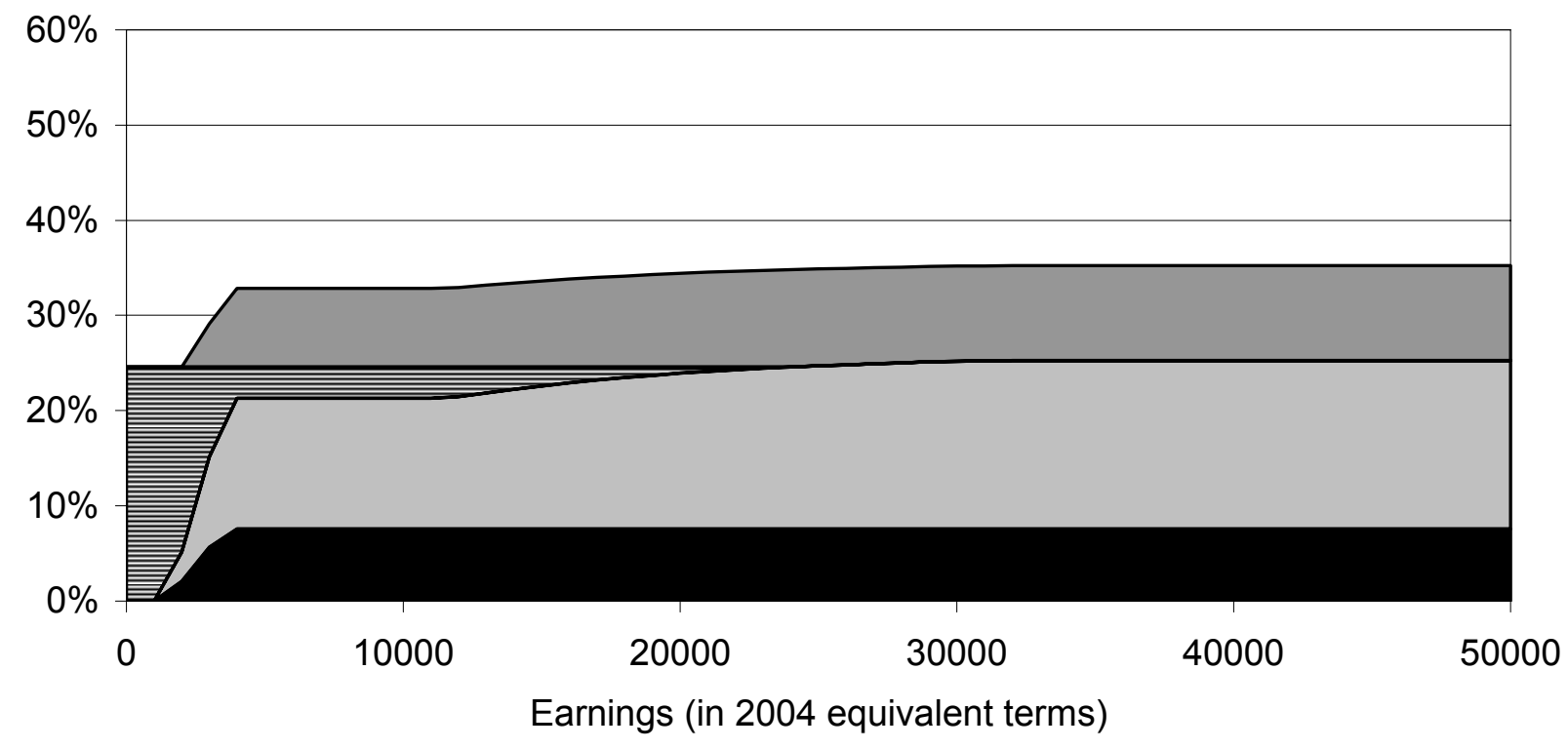

BSP $\square$ SERPS/S2P 目Guarantee Credit $\square$ Savings Credit

Source: PC (2005), figure 4.7. 
Despite those reductions in its generosity for individuals in particular circumstances, if the state system continued to evolve in this way, its cost would rise as a share of GDP. Figure 7 shows the Commission's projection, based on the Department for Work and Pensions (DWP) model, Pensim 2. Care should, of course, be used in interpreting any such projections, based on just one set of a multiplicity of assumptions about future demography, labour markets, and savings behaviour. However, they give a useful base for examining the implications of changes to policy. Spending on state pensions and other cash benefits for those over state pension age would rise in this base case from 6.2 per cent of GDP now to 7.6 per cent of GDP in 2050. This increase - also shown in the government's own most recent projections (HM Treasury, 2005, table 5.1) - is hardly surprising given the projection that there will be 6 million more people over 65 by 2050 .

\section{Figure 7: Public spending on pensioner benefits as \% of GDP (if current indexation arrangements continued indefinitely)}

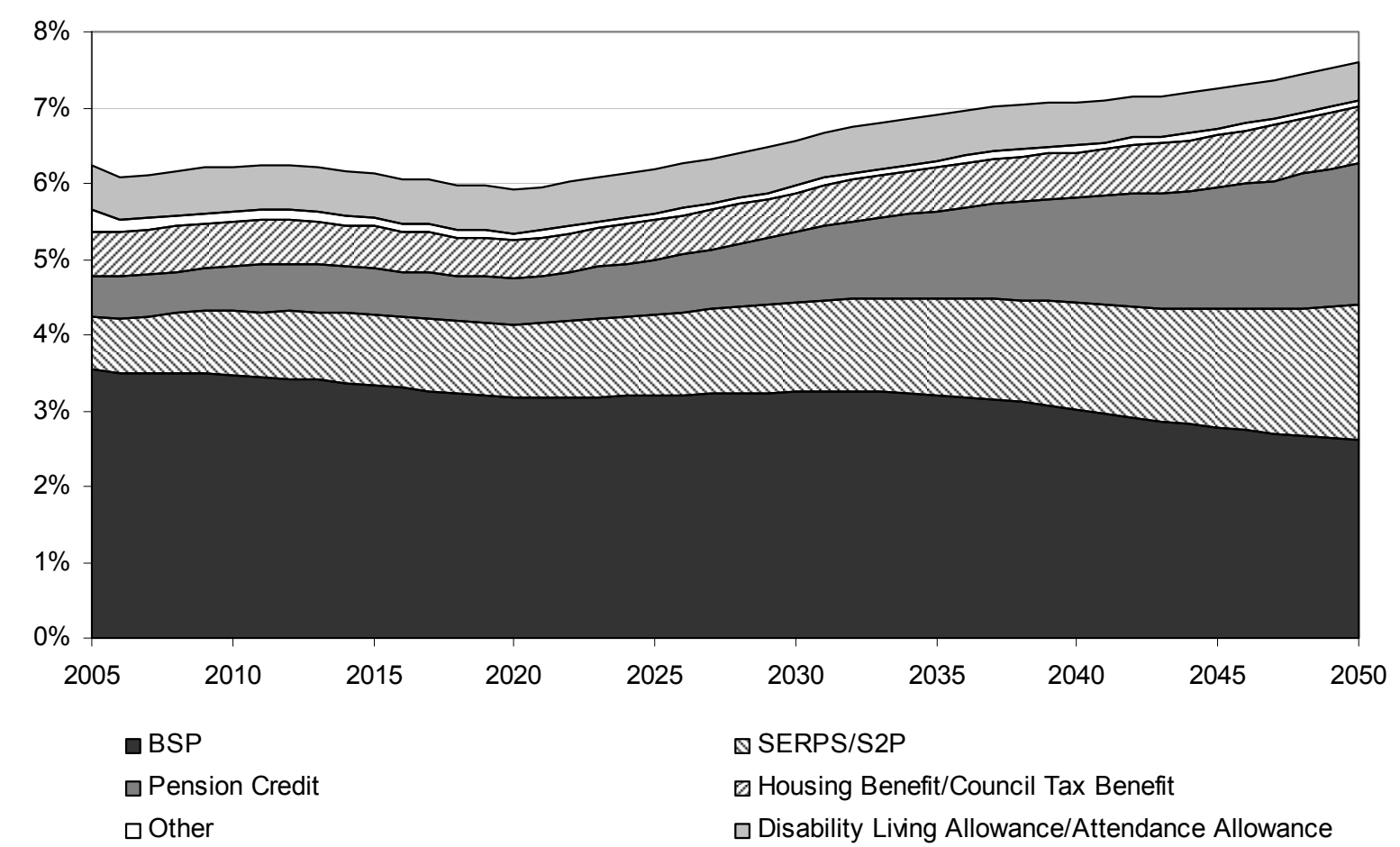

Source: PC (2005, figure 1.19) based on results from DWP's Pensim 2 model.

As the figure shows, within the rising total a roughly constant proportion of national income would be spent on the national insurance-based basic and second state pensions together, but means-tested top-ups would increase, the cost of Pension Credit quadrupling from 0.5 to 2 per cent of GDP. This reflects the way in which, as other state and private sources of pension income fell, an increasing proportion of pensioners would become entitled to means-tested 
assistance through the Pension Credit. With the base case assumptions used in Figure 7, the proportion of all single or couple pensioners subject to meanstesting through Pension Credit would rise steadily from about 40 per cent now to 75 per cent by 2050 (PC, 2005, figure 6.5). Note that in this world, even if we did away with the new part of Pension Credit, the Savings Credit, 40 per cent of pensioners would - unless they increased saving in the face of this wider prospective means-testing - end up needing the Guarantee Credit (what used to be called Income Support or National Assistance) just to get their incomes up to the State's minimum, unless that minimum itself was reduced, at the cost of increased pensioner poverty. This compares with just under 25 per cent in this position today.

The complexity of this potential system, and the widespread belief that potential means-testing might mean a low return on pension saving, are both barriers to private saving increasing in the way governments have hoped for.

But there are inherent barriers too. For those with low- to middle-incomes saving individually outside large occupational schemes, costs are high. Annual Management Charges (AMCs) for "stakeholder pensions" sold to individuals are now capped at 1.5 per cent of accumulated savings for the first ten years, and then to 1 per cent. This gives an average cost even for someone contributing for a long period and with relatively high earnings of around 1.3 per cent per annum, a sizeable slice of a long run real return that might reasonably be expected to be between 3-4 per cent. At such charges - despite being much lower than charged on personal pensions in the past - people's pension pots are likely to end up 20-25 per cent smaller than if they had the $0.2-0.3$ per cent costs enjoyed by large occupational schemes. This does not necessarily reflect excessive profit-making by the insurance companies which sell such pensions: selling and running individual pensions involve large lump sum costs per policy which absorb a high proportion of small savings (PC, 2005, figure 1.25). Indeed, at the stakeholder capped level of costs, trying to sell pensions to those with below median earnings is not an attractive commercial proposition for the providers. 


\section{Objectives of pension policy}

So even if the state system was simpler, less means-tested and more stable we do not believe that voluntary pension provision will revive by itself. Does that mean we should compel people to save a certain amount, e.g. to achieve the at least two-thirds replacement of earnings most ${ }^{4}$ say they want?

But people are wary about this. The focus groups conducted for the Commission suggested that people both wanted to "have to save", but not to be "compelled" (PC, 2005, appendix D1). And if you do compel people, how much should you do so, given their widely varying situations, views of adequate income, housing assets and perhaps future inheritances?

This was the challenge facing the Commission. It was easy to have sympathy with one of Beveridge's conclusions:

"The problem of the nature and extent of the provision to be made for old age is the most important, and in some ways the most difficult, of all the problems of social security" (1942, para. 233).

And as a Commission we took one of his principles as read:

"Any Plan of Social Security worthy of its name must ensure that every citizen ... can claim as of right when he is past work an income adequate to maintain him ... a pension on retirement from work which is enough for subsistence, even though the pensioner has no other resources" (1942, para. 239).

But crucially we agreed with a second of his fundamental principles:

"... social security must be achieved by cooperation between the State and the individual ... The State in organising security should not stifle incentive, opportunity, responsibility; in establishing a national minimum, it should leave room and encouragement for voluntary action by each individual to provide more than that minimum for himself and his family" (1942, para. 9).

In fact we go further than this partnership between individual and state. The lecture on which this paper is based was delivered on the fiftieth anniversary of Richard Titmuss's famous lecture on "the social division of welfare", which drew attention to the importance of "occupational welfare" (Titmuss, 2001). The role of employers in pension provision is still crucial today - but is very

$4 \quad$ PC (2005), appendix D, figures D.28 and D.29. 
varied and in retreat, even though making employer pension contributions is a highly tax-efficient way of paying people. Our approach echoes not just Beveridge, but also Lloyd George's famous "9 pence for 4 pence" offer from the combined role of individual, employer and state.

But where we part company with Beveridge is on the role of the state. Beveridge's view was of a non-redistributive system - flat rate contributions (the "stamp") for flat rate benefits. As people such as Howard Glennerster and Martin Evans (1994) have pointed out, this was the undoing of the original Beveridge scheme. There were never enough resources to get people above the subsistence minimum if National Insurance was funded by a kind of poll tax. And provision beyond the minimum was patchy and unequal in terms of what replacement rates people could achieve.

There are varied views on this. At one end, some have argued that the State's role should or can only be that of poverty relief. At the other, people argue that it is the state which should organise and provide earnings-replacement for all or nearly all, as indeed has been the case in many continental European countries.

But if the State's role stops at poverty relief, many will end up discovering themselves under-provided for or will pay very high costs to get what they want. On the other hand, we tried earnings-replacement when the State Earnings Related Pension Scheme (SERPS, now transmuted into the state second pension) was introduced in 1978, but we never really accepted the cost. We paid for it by reducing the cost of the flat-rate BSP through the price-linking of the last twenty-five years (Hills, 2004). The low-paid, women, and the selfemployed were the losers. The most recent reforms - and the move to the complex flat rate system described above - can be seen as ways of trying to wind back this clock. Taking the longer view, in three generations we would have returned to something not so far from the flat rate system based around the basic state pension established following the Beveridge report, but achieved in a much more complicated way.

At their heart, the Commission's conclusions accept the arguments put to us that the state should concentrate its redistributive power on providing a minimum platform on which people can build. But its role does not stop there. We argue that the state should:

$>$ Ensure that all people are kept out of poverty in retirement;

$>$ Encourage people to achieve at least a base-load of earnings-related pension provision; and

$>$ Enable all people to save for a pension at low cost. 
To achieve this we propose three linked directions for reform:

> Establishing a low cost National Pension Saving Scheme (NPSS), with employees automatically enrolled into either this or good quality existing employer schemes. Individuals would have the right to opt out, but also to make additional contributions beyond the automatic minimum.

$>$ Underpinning this with a state pension reform which would deliver more generous, more universal, less means-tested and ultimately simpler state pensions. Over the long-term this would require both some increase in the percentage of GDP devoted to state pensions and an increase in the State Pension Age (SPA).

$>$ As a corollary of a rising SPA, the state should facilitate later and more flexible retirement, and make sure that implementation of reform is sensitive to differences in life expectancy by socio-economic group.

\section{State system reforms}

It is simplest to start with proposals for the state system, as this sets the framework for what extra would be needed to achieve any given target retirement income from the NPSS or existing occupational schemes. There are many different ways of achieving the kind of flat-rate platform we describe. But if, first, a system is to achieve an adequate platform on which people can build without means-testing spreading still further, and second, to have at its heart the ability of women to have an independent income in retirement (a very different assumption from that made by Beveridge), demography implies that in the longrun both the SPA and public spending will have to rise. How much each does so is a trade off. The lower and upper limits of the "proposed range for debate" in Figure 8 below show the range of public spending needed to deliver a pension on an independent basis which would match the amount currently given by the Guarantee Credit for a single pensioner (plus the cost of extra items such as disability and housing benefits).

In the short-term there are of course gaps in provision, but many people are currently reaching retirement with good rights from SERPS/state second pension and private defined benefit pensions. Indeed, the generation recently retired or now nearing retirement has, taken as a whole, better pension rights than their predecessors enjoyed or their successors are likely to enjoy. To achieve structural reform, the case for higher public spending than now comes after 2020. However, as Figure 7 shows, the already planned increase in women's SPA to 65 between 2010 and 2020 would on current assumptions lead to a fall in spending as a share of GDP. This could be seen as creating some latitude for changes that would begin to build long-term reforms within roughly constant spending as a share of GDP up to 2020. 
In dealing with increasing longevity, there is a strong argument that equity between generations implies that the SPA should rise in proportion to life expectancy in some way. Indeed, if we were only dealing with increased longevity, this could allow fixed spending as a share of GDP. But we are not we are now facing the impact of the fertility declines after the baby boom (Figure 2). Putting all of the cost of this on the near-retirement generation by increasing SPA far faster than life expectancy would seem unfair. This leaves the range shown in Figure 8.

The least aggressive approach would be to say that once SPAs for men and women are equalised at 65 in 2020, the proportions of adult life spent in retirement should be kept constant. At that point the Government Actuary's Department's most recent principal projections would imply average life expectancy at 65 for men and women together of 22 years. Noting that that is half of adult life since 21 , one could, for instance, establish a "two for one" rule - two years after 21 before SPA for every expected year after it. That kind of rule might take the SPA to 67 by 2050 under current projections - but with the implication that spending would need to reach around 8 per cent of GDP compared to 6.2 per cent today.

At the other end, it is hard to imagine a reform being politically acceptable in which the expected length of life after pension age actually shrank from where it is now. That would put a limit - again on current projections - of about 69 by 2050, which would allow required public spending to be somewhat lower, at around $7 \frac{1}{2}$ per cent of GDP.

This is the kind of structural trade-off that faces us. Note that while this is the uncomfortable message that both pension ages and spending on pensioner benefits as a share of national income need to rise after 2020, in both cases the rise is gradual. The range means for instance that today's 50 year-olds, men and women, would still have an SPA of 65 as already expected, but today's 40 yearolds could expect something around one year higher, at $66 . .^{5}$

There are several different ways one could design a more flat-rate, less meanstested state pension that achieves Beveridge's "room and encouragement for voluntary action" for individuals to provide more than the minimum. Our second report discusses in detail the pros and cons of some alternatives, but in the space available it is only possible to sketch out the option which after detailed analysis we believe offers the best way through the competing criteria. We suggest that, faced with the huge complexity of where we start from, it is

5 The Government's White Paper proposals are in the upper half of this range, with SPA proposed to rise to 66 between 2024 and 2026 and to 68 by 2046 . 
actually simpler to evolve from where we are, than to face what turn out to be huge transitional complexities of a "big bang" introduction of a new system. What we propose as our preferred way forward has five elements:

$>$ Building on recent reforms to the state system, accelerating the evolution of the State Second Pension to become flat-rate, but with improved credits for those caring for children or for elderly or disabled people.

$>$ Indexing the Basic State Pension to average earnings growth rather than prices over the long term so that it stops losing relative value, and moving accruals of rights to it onto a universal, residence-based basis (as opposed to the current contributory basis).

$>$ Maintaining the progress in reducing pensioner poverty achieved by the introduction of Pension Credit, but limit the spread of means-testing by freezing the real value of the maximum Savings Credit (the part paid to pensioners with income just above Guarantee Credit level).

$>$ Gradually increase State Pension Age after 2020 in line with increasing life expectancy to reach between 67 and 69 by 2050 .

$>$ Ideally make payments of the basic state pension on a universal basis to all individuals mid-way through retirement, say aged over 75 (to cope with the way in which older generations of women in particular were able only to build up partial rights to it).

If all the elements of that except the last (which has short-term, rather than longterm costs) were implemented, the costs (subject to the usual health warnings about such projections) are shown in Figure 8 by comparison with both current spending and those that would arise from the way the system is currently evolving (as in Figure 7). The solid line shows their trajectory if the rise in SPA after 2020 reached 68 by 2050 for today's 23-year-olds, and the dots showing where it would reach on rules implying more or less rapid change in the SPA. Such an increase in spending would, of course, be painful for tomorrow's taxpayers, but it would be to a level below that which many other countries have already reached, even before their less favourable demography kicks in.

Such a reform would in combination with our other proposals allow, instead of an increase in the numbers affected by means-testing through Pension Credit, a decrease, both in the proportion of pensioners affected at all from today's levels of 40 per cent to around one third, and in the numbers requiring to claim Guarantee Credit to make their income up to the State's minimum from 25 per cent today to around 15 per cent (PC, 2005, figure 6.42).

It also means that instead of a reduction in the replacement rate from nonmeans-tested pensions the state would be offering a typical earner in midretirement from its current level, it would be slightly higher (PC, 2005, figures 6.4 and 6.19). Low-paid workers and those with interrupted paid work careers 
would be better off than their equivalents today, particularly if they had even a small level of savings. ${ }^{6}$

Figure 8: The public spending - state pension age trade-off

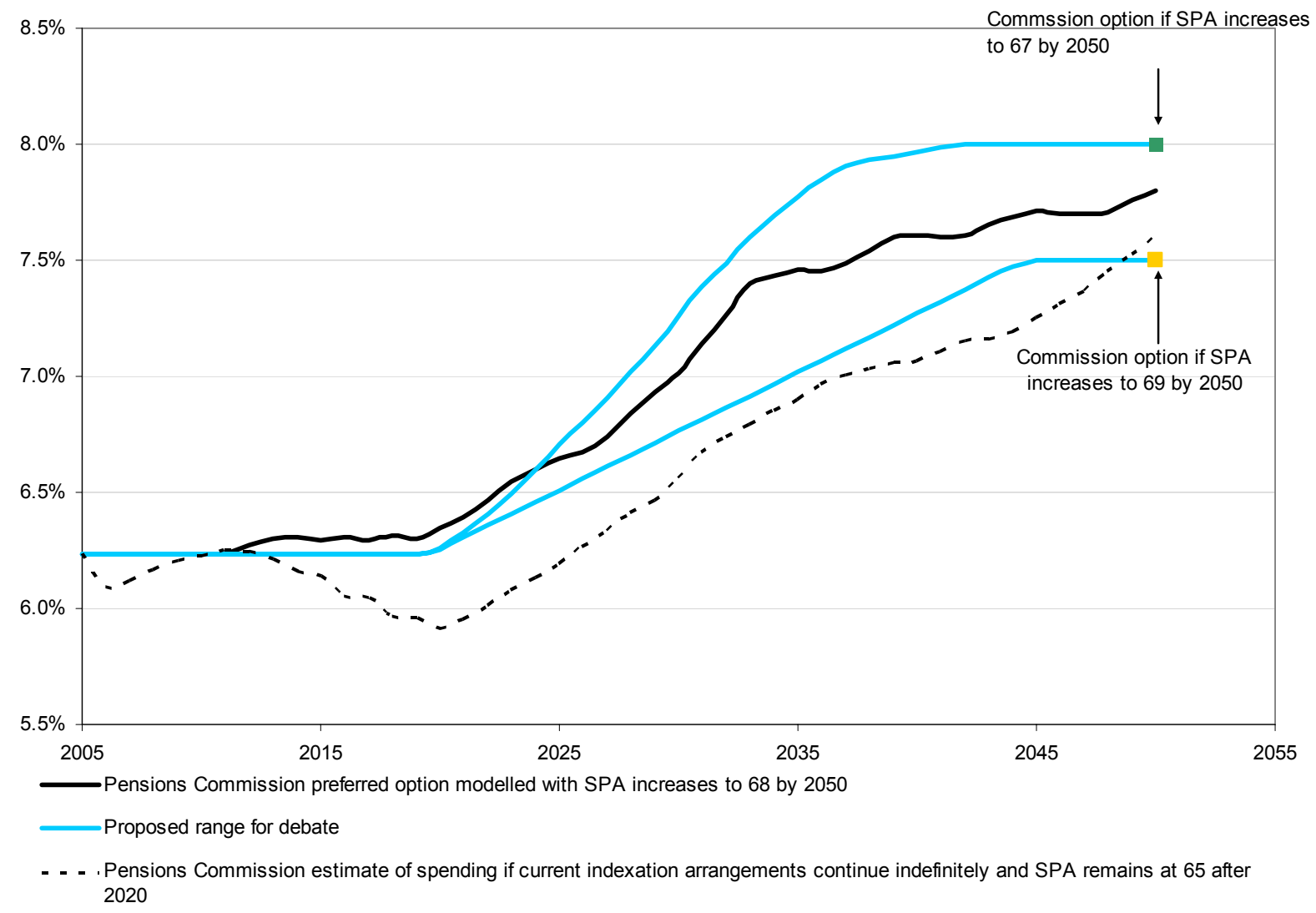

Source: PC (2005, figure Ex. 5).

\section{Encouraging savings and the National Pension Savings Scheme}

Crucially, reforms of this kind to the state system would mean that people were not losing the benefit of their pension saving through reduced Pension Credit, as they would if means-testing spread in the way that it would if current indexation arrangements were to continue indefinitely. This gives the underpinning needed

The Government's White Paper proposals are largely to accept this package with two main modifications. First, indexation of the Basic State Pension to earnings is planned to start in 2012 (if resources allow), rather than the 2010 proposed by the Commission, so that its long-term value will be slightly lower. Second, instead of residence-based accrual of rights to the BSP and universal payment of it at 75, a series of changes to contribution conditions from April 2010, notably a reduction of the number of qualifying years to receive a full BSP to 30, are intended greatly to increase the proportion of women entitled to a full BSP. 
for the second leg of the Commission's proposals - the message that, except for those in very unusual circumstances, saving for retirement is a good deal, and so enrolment in the National Pensions Saving Scheme is an offer you would not want to refuse.

It also sets the challenge for how much might be needed. As we set out in our second report, the wide variations in people's circumstances and preferences means that we are a little cautious in the aims we set for the state to use the power of inertia in strongly encouraging people to build up a base-load of earnings-replacement retirement income through a system of automatic enrolment into the NPSS. For instance, if 45 per cent were set as the minimum base-load replacement rate to be aimed at for a median earner, the state system we suggest as outlined above would get two-thirds of the way there. Another 15 per cent would be needed from private saving on top. To get that, someone starting saving at 30 would need contributions equal to about 6 per cent of total gross pay. ${ }^{7}$ We therefore suggest the following structure of default contributions into the NPSS, into which everyone would be automatically enrolled, unless their employer was automatically enrolling them into a good quality occupational scheme: 8

$>$ Minimum default contributions set at about 8 per cent of earnings between the income tax threshold (currently just under £5,000) and an upper limit (equivalent, say, to the current upper earnings limit for National Insurance Contributions).

$>$ Half of this, 4 per cent, would come from the employee's net pay.

$>1$ per cent would come (for a basic rate taxpayer) from tax relief.

$>$ There would be a compulsory minimum employer contribution of 3 per cent.

Depending on participation rates, this last element would have an aggregate cost (after tax and National Insurance Contribution relief) of about 0.6 per cent of labour costs. It would allow the message that for the default contributions there would be a pound for pound match of the employee's net contributions from net pay. It would also help to ensure that the danger of people ending up with low rates of return on their own savings as a result of means-testing was minimised, which would be crucial to allowing the introduction of automatic enrolment into

7 For sensitivity of this estimate, see PC (2005), figure 6.29. The figures in the text assume a real rate of return on assets of 3.5 per cent, retirement age of 67 , and annual management charges for the NPSS of 0.3 per cent of accumulated assets.

8 Again, the Government's White Paper proposals follow the recommended structure, although the start date is proposed to be 2012, and the Government is still consulting on how the NPSS or an equivalent system of "personal accounts" should be run. 
the NPSS (or any equivalent system) without the need for expensive individual advice about participation. ${ }^{9}$

But we could also use the NPSS as a way of enabling people to save more at low cost through extra voluntary contributions to it - we suggest up to twice the default amount for a median earner. This would allow them to get close to the two-thirds replacement rate people around median earnings tend to set as their objective. Put together, the state reforms and the NPSS proposals would build up in the way shown in Figure 9. For someone who spent the bulk of their working age life in the UK either in paid work or in caring activities the basic and second state pensions together would deliver at the point of retirement at the State Pension Age around 30 per cent of median earnings. Depending on the proportion of this time that they remained in the automatic enrolment part of the system, a median earner would receive a further 15-18 per cent of median earnings from the automatic enrolment part of the NPSS, with the option to double this.

\section{Figure 9: Pension income as percentage of earnings for median earner at point of retirement}

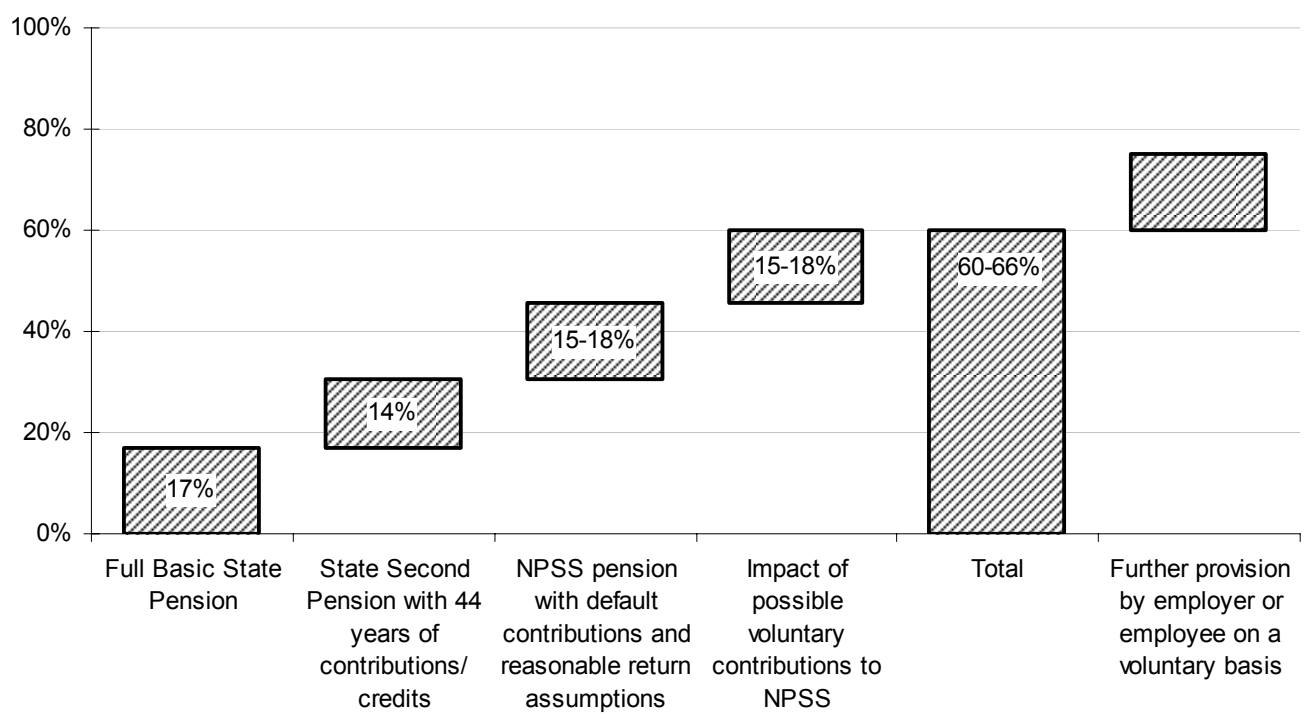

Source: PC (2005, figure Ex. 7).

The funds in the NPSS would be invested at each individual's discretion - but generally in bulk-bought funds of different kinds at the low management costs this kind of system would allow. People would be building up their own asset -

9 For more detailed discussion of the issues around the compulsory employer matching contribution, see PC (2006), section 4. 
potential funds worth up to $£ 161,000$ (relative to contemporary incomes) for someone on median earnings saving at double the default rate.

The lead times involved for the scheme to reach maturity are of course long, but on reasonable assumptions by 2050 it would be producing the 0.6 per cent of GDP needed to offset the likely fall in private pension savings we foresee (PC, 2005, figure 6.39). The outflow from it as income to pensioners could, depending on the rate of additional contributions and participation reach between 0.6-1.0 per cent of GDP in 2050, rising quickly to between 0.8 and 1.3 per cent of GDP by 2060 (PC, 2005, appendix F, figure F42).

\section{Distributional impact}

Put together, we think this is a progressive package involving the painful realities of later retirement, higher revenues needed for state provision in the long run, and greater private saving, but offering a better deal to women, carers and the low-paid than is now on offer. Key elements in achieving this include:

$>$ The NPSS would open up low-cost pension saving to those previously excluded from it because their contributions would be too low.

$>$ The very lowest income pensioners (those who currently fail to claim the Guarantee Credit) would gain from more automatic rights to earningslinked state pensions

$>$ State pension spending would increasingly be concentrated on individual rights to a flat-rate minimum:

- $\quad$ The indexation of the basic state pension to earnings would halt decline in its relative value

- Future accruals to rights to the basic pension would be on a universal (residence before retirement) basis

- Credits for carers towards the state second pension would be improved

As a result there would be reduced reliance on benefits based on a family means-test, rather than the increase in reliance which would occur under existing arrangements.

$>$ The desirable addition of payment of the basic pension on a residency basis to all individuals aged over 75 (building on existing 'Category D' pensions).

But to set alongside this, there is a further key issue. The trends in life expectancy discussed at the start of the paper are of course averages. As Sir Michael Marmot (2003) discussed in his RSS Beveridge Lecture, there are shamefully large differences in life expectancy by social class. Earlier figures, such as in Figure 1, show cohort life expectancies, allowing for anticipated 
future improvements in age-specific mortality. By contrast the recent trends in life expectancies by social class shown in Figure 10 are for period life expectancies at 65 - how long people would live in a "Groundhog Day" world with their future lives trapped, for instance, in the late 1990s. They therefore understate how long we would expect each cohort actually to live as they move through real time. But the differences between social classes are a reasonable guide - five years between the least and most favoured social groups of men still. And while all social groups have gained, the gaps show no sign of narrowing. As a corollary the proportionate - but not absolute - impact of an increase in State Pension Age on, for instance, manual workers would be greater than that on professional workers. While this should not be a reason to avoid the inevitability of state pension ages rising with life expectancy to create the sustainable system that is in the interests of all who will depend on it, it means it is essential that any reform taken as a whole has to be progressive in its impact.

It also means that as a corollary of pension reform, it has to be a very high priority to address the causes of such inequalities - laid out, for instance, in Michael Marmot's lecture - crucially doing so earlier in people's working lives. It is, after all, those currently aged 40 or under who would be affected by our proposals for a gradual increase in SPA. But long-run pension reforms also need to be accompanied by an agenda that facilitates later working and gradual, rather than sudden, moves into retirement. We discuss these in more detail in Chapter 8 of our second report, but potential elements include:

$>$ Allowing earlier claim of Guarantee Credit for those with low incomes than the gradually increasing SPA (for instance, the age for claiming Guarantee Credit could remain stay at 65 after 2020 as the SPA rose).

$>$ Examining an option for lower pension age for the basic pension and a higher for the state second pension.

$>$ Remove the default retirement age of 65 from anti-age discrimination legislation

$>$ Widening public knowledge of advantages of deferring claiming state pensions (the amount paid now rises in perpetuity by 10 per cent for each year of deferral) and allowing people to claim part of their state pension but defer the rest as in Sweden, for instance to support continued parttime work.

$>$ Giving incentives to employers to hire workers above SPA, for instance through reduced employer National Insurance Contributions.

\section{Conclusion}

Our report does not talk about an immediate crisis in pensioner incomes. There are gaps and inequities, of course, which many would want to rectify if they 
could find the resources to do so. But it is looking 15 to 20 years ahead that we see major structural deficiencies and inequities. That interval should not be an excuse for deferring decisions. The Green Paper exploring equalisation of men and women's pension ages was published in 1991. The changes it led to start in 2010. The last widow benefiting from the pensions given for veterans of the US civil war in the nineteenth century died only recently. Pension reforms have long lead times and take a long time to work their way through. What we have now is an opportunity to build a consensus on the way forward, not a reason for inaction.

There may have been queues round the Stationery Office when Beveridge's report was published on 2 December 1942. But the queues were probably longer for the film Casablanca, released a week earlier. Those who have seen it will remember the moment when Humphrey Bogart explains to Ingrid Bergman why she has to get on the plane with the dull but important Victor Lazlo, rather than staying with him.

We are in the same position on pension reform. As Bogart might have put it, if we miss the opportunity we have now to construct a way forward, we'll regret it. Maybe not today. Maybe not tomorrow. But soon, and for the rest of our (hopefully lengthening) lives. 


\section{References}

Beveridge, Sir W. (1942) Social Insurance and Allied Services, Cmd. 6404. London: HMSO.

Department for Work and Pensions [DWP] (2006a) Households Below Average Income: An analysis of the income distribution 1994/5 - 2004/5. Leeds: Corporate Document Services.

DWP (2006b) Security and Retirement: Towards a new pensions system, Cm.6841. London: TSO.

Government Actuary's Department (2005) 2004-based Principal Population Projection, UK. London: GAD.

Glennerster, H. and Evans, M. (1994) 'Beveridge and his assumptive worlds: The incompatibilities of a flawed design', in Beveridge and Social Security: An international retrospective (eds. J. Hills, J. Ditch and H. Glennerster). Oxford: Oxford University Press.

Hills, J. (2004) 'Heading for retirement? National Insurance, state pensions, and the future of the contributory principle in the UK', Journal of Social Policy, 33: 347-72.

HM Treasury (2005) Long-term public finance report: An analysis of fiscal sustainability, Pre-Budget Report document. London: HM Treasury.

Marmot, M. (2003) 'Social inequalities in health', RSS Beveridge Lecture, 7 May 2003 (mimeo).

O’Brien, C., Fenn, P. and Diacon, S. (2005) How Long do People Expect to Live? Results and implications. Nottingham: Centre for Risk and Insurance Studies, University of Nottingham.

Office for National Statistics [ONS] (2005) Trends in life expectancy by social class 1972-2001, ONS Longitudinal Study, England and Wales. London: ONS.

Pensions Commission (PC) (2004) Pensions: Challenges and choices, first report of the Pensions Commission. London: TSO.

Pensions Commission (PC) (2005) A New Pension Settlement for the Twentyfirst Century, second report of the Pensions Commission. London: TSO.

Pensions Commission (PC) (2006) Implementing an Integrated Package of Pension Reforms, final report of the Pensions Commission. London: TSO. 
Sutherland, H. (2004) Poverty in Britain: The impact of government policy since 1997. An update to 2004-5 using microsimulation. Cambridge: Microsimulation Unit, Cambridge University.

Taylor-Gooby, P. (2005) 'Uncertainty, trust and pensions: The case of the UK reforms', Social Policy and Administration, 39(3): 217-32.

Titmuss, R. (2001) 'The social division of welfare: Some reflections on the search for equity', in Welfare and Wellbeing: Richard Titmuss's contribution to social policy (eds. P. Alcock, H. Glennerster, A. Oakley and A. Sinfield). Bristol: Policy Press. (Lecture in honour of Eleanor Rathbone originally delivered in 1955). 